\title{
New earthworm records from several Indian Ocean islands (Clitellata, Megadrili)
}

\author{
T. SZEDERJESI ${ }^{1}$, T. PAVLÍČEK ${ }^{2} \&$ Cs. $^{2}$ CSUZDI $^{3}$ \\ ${ }^{1}$ Tímea Szederjesi, Department of Zoology, Hungarian Natural History Museum, Budapest, Hungary. \\ E-mail:t.szederjesi@gmail.com \\ ${ }^{2}$ Tomás Pavlíček, Institute of Evolution, University of Haifa, Israel. \\ ${ }^{3}$ Csaba Csuzdi, Department of Zoology, Eszterházy Károly University, Eger, Hungary.
}

\begin{abstract}
Elaboration of the earthworm material collected on the Seychelles, Mauritius, Réunion, Mayotte and Sri Lanka islands resulted in recording 20 species altogether. Among them, the ocnerodrilid Maheina braueri (Michaelsen, 1897) endemic to Mahé (Seychelles) and the megascolecid Nellogaster bahli (Stephenson, 1925) endemic to Sri Lanka were reported for the first time since their original description. The material also contained some enigmatic juvenile specimens from Mayotte, most resembling the genus Diporochaeta.
\end{abstract}

Keywords. Oligochaeta, Ceylon, Seychelles, Mauritius, Reunion, Mayotte.

\section{INTRODUCTION}

$\mathrm{T}$ he Indian Ocean is the third largest ocean on the globe bordered by Africa, Asia, Australia and Antarctica (Fatima \& Jamshed 2015). It has numerous small and several larger islands of different origin from continental (e.g. Madagascar, Seychelles) to true oceanic ones (e.g. Reunion, Mauritius) (Walker et al. 2005). Madagascar, with the other Indian Ocean Islands, represents one of the Earth's 35 biodiversity hotspots (Mittermeier et al. 2011). However, except Madagascar of which the earthworm fauna has recently been intensively studied (Csuzdi et al. 2012, 2016, 2017a, Hong et al. 2018, Razafindrakoto et al. $2010,2011,2017)$ earthworms of the other islands of this hotspot are almost unknown. Apart from some sporadic records (Michaelsen 1897a, 1907a) there are just a few comprehensive publications from the region including the summary of the earthworms in the Seychelles Islands by Gerlach (2011) and that of Mauritius by Ljungström (1971).

Gerlach (2011) listed 11 earthworm species from the families Eudrilidae, Megascolecidae, A- canthodrilidae and Octochaetidae. Apart from the obviously erroneous placements of the megascolecid Lampito mauritii Kinberg, 1866 to Octochaeatidae and the glossoscolecid (now rhinodrilid) Pontoscolex corethrurus (Müller, 1857) to Acanthodrilidae he also listed several strange lumbricid species (with 20-25, 25-33 and 10-15 setae per bundle (sic!)). The native Maheina braueri (Michaelsen, 1897) described from Mahé Island was listed in Acanthodrilidae but have not been re-collected during the collections conducted in the early 1970s and 2000s.

Ljungstöm's (1971) checklist of the earthworms of Mauritius lists ten species; all are wellknown peregrine ones with Amynthas species prevailing (listed in the genus Pheretima).

Sri Lanka, with its some $65,000 \mathrm{~km}^{2}$ territory represents the second largest island in the region after Madagascar. It is a continental island lying on the Indian Plate and, together with the Western Ghats represents an independent biodiversity hotspot in the Indian Ocean region (Katz 2000, Mittermeier et al. 2011). Due to the works of Michaelsen (1897b, 1903, 1907b, 1908, 1910) and Stephenson $(1913,1915,1923,1925)$ its earth- 
worm fauna is quite well studied recording 63 earthworm species for the island including 48 endemics.

Here we provide new earthworm records collected in the early 2000's years in Mauritius, Mayotte, Reunion, Seychelles and Sri Lanka. A small collection by the USSR Zoological Expedition to Seychelles was also elaborated.

\section{MATERIAL AND METHODS}

Earthworms were collected with the diluted formalin method (Raw 1959) supplemented by digging and searching under stones, barks of fallen logs and mosses. The specimens collected were killed in $75 \%$ ethanol, fixed in $4 \%$ formalin and after several days transferred into $75 \%$ ethanol. The gathered specimens are deposited in the earthworm collection of the Hungarian Natural History Museum (HNHM).

\section{TAXONOMY}

Family Acanthodrilidae Claus, 1880

\section{Dichogaster (Diplothecodrilus) annae (Horst, 1893)}

Benhamia annae Horst, 1893: 32.

Dichogaster (Diplothecodrilus) annae: Csuzdi 2010: 191. (for complete synonymy)

Material examined. HNHM/AF5171 5 ex., Mayotte, Grande Terre, along River Bandrani, S1242’26” E4505'36”, 160 m, 07.10.2005, leg. T. Pavlíček. HNHM/AF5177 2 ex., Mayotte, Grande Terre, along Longoni River, S12 ${ }^{\circ} 44^{\prime}$ E4510', 95 m, 05.10.2005, leg. T. Pavlíček. HNHM/AF5735 2 ex., Seychelles, Mahé, Copolia, the beginning of the road, under bark, 16.06. 2000, leg. Cs. Csuzdi.

\section{Family Eudrilidae Calus, 1880}

\section{Eudrilus eugeniae (Kinberg, 1867)}

Lumbricus eugeniae Kinberg, 1867: 98.

Eudrilus engeniae: Blakemore 2008a: 452 (for complete stynonymy).
Material examined. HNHM/AF5192 3 ex., Mayotte, Grande Terre, along the river above the Gîtes de Kwalé, S1248'30” E4509'40”, 185 m, 06.10.2005, leg. T. Pavlíček.

\section{Family Lumbricidae Rafinesque-Schmaltz, 1815}

\section{Aporrectodea caliginosa (Savigny, 1826)}

Enterion caliginosum Savigny, 1826: 180. Aporrectodea caliginosa: Csuzdi \& Zicsi 2003: 75 (for complete synonymy).

Material examined. HNHM/17515 2 ex., Réunion, Piton des Neiges, ca. $2000 \mathrm{~m}$ asl., 16.09. 2002.

\section{Bimastos rubidus (Savigny, 1826)}

Enterion rubidum Savigny, 1826: 182.

Bimastos rubidus: Csuzdi et al. 2017b: 20.

Material examined. HNHM/17516 2 ex., Réunion, Piton des Neiges, ca. $2000 \mathrm{~m}$ asl., 16.09.2002.

\section{Family Megascolecidae Rosa, 1891 \\ Amynthas corticis (Kinberg, 1867)}

Perichaeta corticis Kinberg, 1867: 102.

Amynthas corticis: Blakemore 2008a: 272 (for complete synonymy).

Material examined. HNHM/AF5717 1 ex., Réunion, the bottom of the moss forest, $c a .1000 \mathrm{~m}$, 22.06.2000, leg. Cs. Csuzdi. HNHM/AF5720 2 ex., Réunion, Forêt de Bébour, $1310 \mathrm{~m}$, moss forest, 22.06.2000, leg. Cs. Csuzdi.

\section{Amynthas gracilis (Kinberg, 1867)}

Nitocris gracilis Kinberg, 1867: 102.

Amynthas gracilis: Blakemore 2008a: 284 (for complete synonymy).

Material examined. HNHM/AF5723 3 ex., Mauritius, Petrin, Brise Fer, forest reserve, behind the Gerald Durrell Endemic Wildlife Sanctuary, $625 \mathrm{~m}, \mathrm{~S} 20^{\circ} 22^{\prime} 1^{\prime}{ }^{\prime} \mathrm{E} 57^{\circ} 26^{\prime}{ }^{\prime}$ ”, 26.06.2000, leg. Cs. Csuzdi. 


\section{Amynthas minimus (Horst, 1893)}

Perichaeta minima Horst, 1893: 66.

Amynthas minimus: Blakemore 2008a: 302 (for complete synonymy).

Material examined. HNHM/AF5713 9 ex., Mauritius, Montagne Cocotte, moss forest, under moss, $750 \mathrm{~m}, \mathrm{~S} 20^{\circ} 26^{\prime} 5^{\prime \prime}$ E $57^{\circ} 28^{\prime} 3^{\prime \prime}, 26.06 .2000$, leg. Cs. Csuzdi. HNHM/AF5721 1 ex., Mauritius, Petrin, Brise Fer, forest reserve, behind the Gerald Durrell Endemic Wildlife Sanctuary, $625 \mathrm{~m}, \mathrm{~S} 20^{\circ}$ 22'1” E57²6'5”, 26.06.2000, leg. Cs. Csuzdi. HNHM/AF5751 1 ex., Seychelles, Silhouette, 23. 08.1984, USSR Zoological Expedition.

\section{Amynthas rodericensis (Grube, 1879)}

Perichaeta rodericensis Grube, 1879: 554.

Amynthas rodericensis: Blakemore 2008a: 319 (for complete synonymy).

Material examined. HNHM/AF5169 1 ex., Mayotte, Grande Terre, along River Bandrani, S12 42'26" E4505'36”, $160 \mathrm{~m}, 07.10 .2005$, leg. T. Pavlíček. HNHM/AF5179 4 ex., Mayotte, Grande Terre, along Longoni River, S12 ${ }^{\circ} 44^{\prime}$ E4510', 95 m, 05.10.2005, leg. T. Pavlíček. HNHM/AF5185 2 ex., Mayotte, Grande Terre, near Longoni, S12 $43^{\prime} 43^{\prime \prime} \mathrm{E} 45^{\circ} 07^{\prime} 46^{\prime \prime}, 35 \mathrm{~m}$, around mangrove forest, 04.10.2005, leg. T. Pavlíček. HNHM/AF5712 1 ex., Mauritius, Montagne Cocotte, moss forest, under moss, $750 \mathrm{~m}$, S20 26' 5" E57'28'3”, 26.06.2000, leg. Cs. Csuzdi. HNHM/AF5718 2 ex., HNHM/AF5716 1 ex., Réunion, the bottom of the moss forest, $c a$. $1000 \mathrm{~m}, 22.06 .2000$, leg. Cs. Csuzdi. HNHM/ AF5722 3 ex., Mauritius, Petrin, Brise Fer, forest reserve, behind the Gerald Durrell Endemic Wildlife Sanctuary, $625 \mathrm{~m}, \mathrm{~S} 20^{\circ} 22^{\prime} 1^{\prime \prime}$ E5 $57^{\circ} 26^{\prime} 5^{\prime \prime}$, 26.06.2000, leg. Cs. Csuzdi. HNHM/AF5728 3 ex., Mauritius, Black River Peak, 600-700 m, 27.06.2000, leg. Cs. Csuzdi.

\section{Amynthas robustus (Perrier, 1872)}

Perichaeta robusta Perrier, 1872: 112.

Amynthas robustus: Blakemore 2008a: 315 (for complete synonymy).
Material examined. HNHM/AF5711 3 ex., Mauritius, Montagne Cocotte, moss forest, under moss, $750 \mathrm{~m}, \mathrm{~S} 20^{\circ} 26^{\prime} 5^{\prime \prime} \mathrm{E}^{\circ} 7^{\circ} 28^{\prime} 3^{\prime \prime}$, 26.06.2000, leg. Cs. Csuzdi. HNHM/AF5716 1 ex., Réunion, the bottom of the moss forest, $c a .1000 \mathrm{~m}, 22.06$. 2000, leg. Cs. Csuzdi. HNHM/AF5727 1 ex., Mauritius, Black River Peak, 600-700 m, 27.06.2000, leg. Cs. Csuzdi.

\section{?Diporochaeta sp.}

(Figures 1-3)

Material examined. HNHM/AF5172 4 ex., Mayotte, Grande Terre, along River Mro, NE of Dzoumonyé, S1241'58' E4505'22”, $200 \mathrm{~m}$, natural forest, 08.10.2005, leg. T. Pavlíček. HNHM/ AF5193 1 ex., Mayotte, Grande Terre, along the river above the Gites de Kwalé, S12 ${ }^{\circ} 48^{\prime} 30^{\prime}$ " E4509’40”, 185 m, 06.10.2005, leg. T. Pavlíček.

Description. External characters. All specimens juvenile. Length around $60 \mathrm{~mm}$, diameter $2.5 \mathrm{~mm}$. Colour alive unknown, conserved pale. Prostomium epilobic, dorsal pores lacking. Segments simple, setae perichaetin in irregular rows with ventral and dorsal interruption, aa $=1.5 \mathrm{zz}$. Setal number on segment III $=22, \mathrm{VI}=26, \mathrm{X}=$ $22, \quad \mathrm{XIII}=20, \mathrm{XVII}=16, \mathrm{XXVI}=14$. Spermathecal pores paired small slits in the intersegmental furrows VII/VIII, VIII/IX in setal line $b$. Clitellum lacking. Female pores in XIV, presetal before setae $a$. One pair of combined male and prostatic pores on XVIII in setal line b. Paired genital markings on XVIII outside of the prostatic pores and in XVII/XVIII and XVIII/XIX in setal line $b$, furthermore a single midventral papilla in XVIII between the prostatic pores (Fig. 1).

Internal characters. No septa notably thickened. Muscular gizzard lacking. Dorsal vessel single throughout, the last pair of hearts in XIII. Excretory system holoic, avesiculate. Calciferous glands lacking. Intestine begins in XVI, typhlosole lacking. Holandric. Two pairs of testes and iridescent male funnels in X, XI. Seminal vesicles two pairs in XI, XII. One pair of ovaries in XIII. One pair of small tubular prostates in XVIII, 

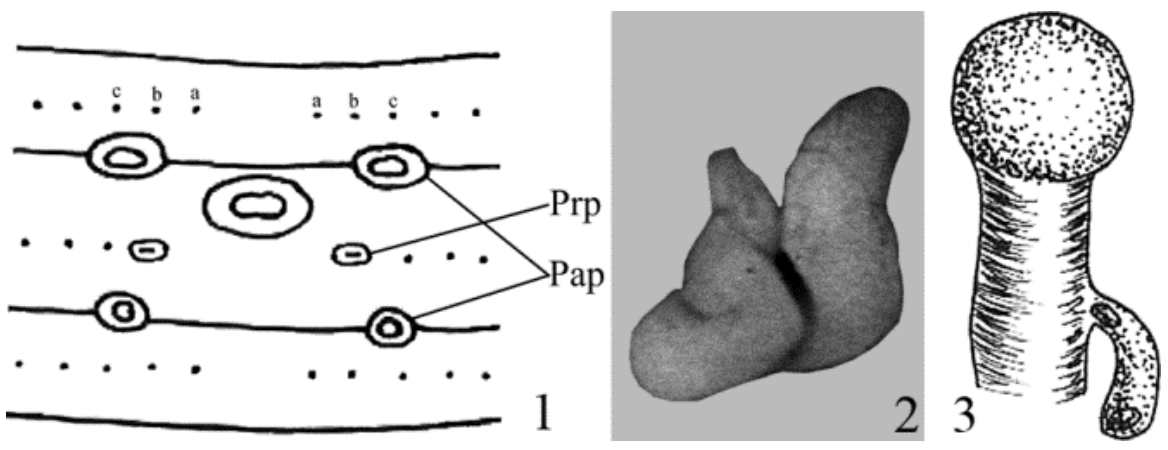

Figures 1-3. Diporochaera sp. $1=$ male field; $2=$ prostate gland; $3=$ spermatheca. Prp $=$ prostatic pore, Pap $=$ papillae

slightly coiled and confined to its own segment (Fig. 2). Penial setae lacking. Two pairs of spermathecae in VIII and IX. Ampulla elongated sacshaped, duct wide, $c a$. 1/3 as long as the ampoule. A small, unilocular, finger-shaped diverticulum joins to the ental part of the duct. (Fig. 3).

Remarks. We have several juvenile specimens from this interesting species. With its non-lumbricine setal arrangement, holoic avesiculate excretory system and tubular prostates, these specimens seem to be most close to the Australian genus $\mathrm{Di}$ porochaeta Beddard, 1890. However, our specimens do not fit clearly to Diporochaeta because they lack muscular gizzard. To clear the position of this interesting species further clitellate material is needed.

\section{Lampito mauritii Kinberg, 1867}

Lampito mauritii Kinberg, 1867: 103, Blakemore 2008a: 238 (for complete synonymy).

Material examined. HNHM/AF5748 3 ex., Sri Lanka, Colombo district, Dehiwala-Mount Lavinia, moist area, 09.03.2000, leg. S. Mahunka, L. Mahunka-Papp. HNHM/AF5749 1 ex., Amirantes, Poivre Atoll, coconut plantation, 05-09.08. 1984, USSR Zoological Expedition.

\section{Megascolex insignis Michaelsen, 1910}

Megascolex insignis Michaelsen, 1910: 78, Stephenson 1923: 250.

Material examined. HNHM/AF5737 7 ex., Sri Lanka, Kalutara district, Matugama, stream bank near the city, 12.03.2000, S. Mahunka, L. Mahunka-Papp. HNHM/AF5741 2 ex., Sri Lanka, Kalutara district, Wadduwa, moist meadow near the city, 11.03.2000, leg. S. Mahunka, L. MahunkaPapp. HNHM/AF5745 6 ex., Sri Lanka, Kalutara district, Moratuwa, near the shore of Bolgoda Lake, 10.03.2000, leg. S. Mahunka, L. MahunkaPapp.

\section{Metaphire bahli (Gates, 1945)}

Pheretima bahli Gates, 1945: 85.

Metaphire bahli: Blakemore 2008a: 338.

Material examined. HNHM/AF5740 2 ex., Sri Lanka, Kalutara district, Wadduwa, a moist meadow near the city, 11.03.2000, leg. S. Mahunka, L. Mahunka-Papp. HNHM/AF5743 1 ex., Sri Lanka, Kalutara district, Kalutara, bare, weedy area at the edge of the city, from cow droppings and soil, 06.03.2000, leg. S. Mahunka, L. Mahunka-Papp. HNHM/AF5746 1 ex., Sri Lanka, Colombo district, Dehiwala-Mount Lavinia, moist area, 09.03 .2000 , leg. S. Mahunka, L. Mahunka-Papp.

\section{Metaphire californica (Kinberg, 1867)}

Pheretima californica Kinberg, 1867: 102.

Metaphire californica: Blakemore 2008a: 343 (for complete synonymy).

Material examined. HNHM/AF5719 1 ex., Réunion, the bottom of the moss forest, $c a .1000 \mathrm{~m}$, 22.06.2000, leg. Cs. Csuzdi

\section{Nellogaster bahli (Stephenson, 1925)}

Woodwardiella bahli Stephenson, 1925: 888. 
Nellogaster bahli: Gates, 1938: 428, 1945: 75.

Material examined. HNHM/AF5739 2 ex., Sri Lanka, Kalutara, 08.03.2000, leg. S. Mahunka, L. Mahunka-Papp.

Remarks. Gates (1938) separated Woodwardiella bahli Stephenson, 1925, into a new genus Nellogaster due to its lumbricine setal arrangement and presence of open enteroic megameronephridia in the postclitellar segments. Blakemore (2007) places this species into Notoscolex Fletcher, 1886 characterized by lumbricine setae and open exoic megameronephridia. Until a thorough revision of the Indian megascolecids is done we retain Gates' (1938) combination.

\section{Pithemera bicincta (Perrier, 1875)}

Perichaeta bicincta Perrier, 1875: 1044.

Pithemera bicincta: Blakemore 2008a: 419 (for complete synonymy).

Material examined. HNHM/AF5167 1 ex., Mayotte, Grande Terre, along River Bandrani, S12 42'26" E4505'36", $160 \mathrm{~m}, 07.10 .2005$, leg. T. Pavlíček. HNHM/AF5173 1 ex., Mayotte, Grande Terre, along River Mro, NE of Dzoumonyé, S12 $41^{\prime} 58^{\prime \prime} \mathrm{E} 45^{\circ} 05^{\prime} 22^{\prime \prime}, 200 \mathrm{~m}$, natural forest, 08.10.2005, leg. T. Pavlíček. HNHM/ AF5181 6 ex., Mayotte, Grande Terre, along River Mro, NE of Dzoumonyé, S1242'55" E45 06'06”, $115 \mathrm{~m}$, natural forest, 11.10.2005, leg. T. Pavlíček. HNHM/AF5184 2 ex., Mayotte, Grande Terre, near Longoni, S12 $43^{\prime} 43^{\prime \prime}$ E $45^{\circ} 07^{\prime} 46^{\prime}$ ', 35 $\mathrm{m}$, around mangrove forest, 04.10.2005, leg. T. Pavlíček. HNHM/AF5732 5 ex., Réunion, lowland rain forest, 24.06.2000, leg. Cs. Csuzdi.

\section{Polypheretima elongata (Perrier, 1872)}

Perichaeta elongata Perrier, 1872: 124.

Polypheretima elongata: Blakemore 2008a: 428 (for complete synonymy).

Material examined. HNHM/AF5160 2 ex., Mayotte, Grande Terre, along River Mroni Bé, N of Dapani, S1557'57” E4509'28”, 40 m, 08.10.
2005, leg. T. Pavlíček. HNHM/AF5162 5 ex., AF5163 3 ex., Mayotte, Grande Terre, Tsimkoura, fruit plantation, $\mathrm{S} 12^{\circ} 55^{\prime} 50^{\prime \prime} \mathrm{E} 45^{\circ} 07^{\prime} 25^{\prime}$, 16.10.2005, leg. T. Pavlíček. HNHM/AF5164 1 ex., Mayotte, Grande Terre, Kwalé, S12 ${ }^{\circ} 47^{\prime} 42^{\prime \prime}$ E4509'57’, 330 m, 20.10.2005, leg. T. Pavlíček. HNHM/AF5168 3 ex., Mayotte, Grande Terre, along River Bandrani, S12 42'26" E45 05'36", 160 m, 07.10.2005, leg. T. Pavlíček. HNHM/ AF5174 2 ex., Mayotte, Grande Terre, along River Mro, NE of Dzoumonyé, S12 $41^{\prime} 58^{\prime \prime}$ $\mathrm{E} 45^{\circ} 05$ '22”, $200 \mathrm{~m}$, natural forest, 08.10.2005, leg. T. Pavlíček. HNHM/AF5178 3 ex., Mayotte, Grande Terre, along Longoni River, S12 $44^{\circ}$ E45 $10^{\prime}, 95$ m, 05.10.2005, leg. T. Pavlíček. HNHM/AF5180 6 ex., Mayotte, Grande Terre, Dembéni, CIRAD station, 12.10.2005, leg. T. Pavlíček. HNHM/AF5182 2 ex., AF5183 2 ex., Mayotte, Grande Terre, along River Mro, NE of Dzoumonyé, S1242'55” E4506'06”, $115 \mathrm{~m}$, natural forest, 11.10.2005, leg. T. Pavlíček. HNHM/AF5186 1 ex., Mayotte, Grande Terre, near Longoni, S12 $433^{\prime} 43^{\prime \prime} \mathrm{E} 45^{\circ} 07^{\prime} 46^{\prime \prime}, 35 \mathrm{~m}$, around mangrove forest, 04.10.2005, leg. T. Pavlíček. HNHM/AF5189 5 ex., Mayotte, Grande Terre, along Longoni River, S12 $44^{\prime}$ E $45^{\circ} 10^{\prime}$, 40 m, 05.10.2005, leg. T. Pavlíček. HNHM/AF5191 1 ex., Mayotte, Grande Terre, along the river above the Gîtes de Kwalé, S12 $48^{\prime} 30^{\prime \prime}$ E45 09'40", 185 m, 06.10.2005, leg. T. Pavlíček. HNHM/AF5715 2 ex., Mauritius, Yemen Grosse Roche, 270 m, grassy meadow, stream bank, 28.06.2000, leg. Cs. Csuzdi.

\section{Polypheretima taprobanae (Beddard, 1892)}

Perichaeta taprobanae Beddard, 1892: 163.

Polypheretima taprobane: Blakemore 2008a: 435 (for complete synonymy).

Material examined. HNHM/AF5738 1 ex., Sri Lanka, Kalutara district, Matugama, stream bank near the city, 12.03.2000, S. Mahunka, L. Mahunka-Papp. HNHM/AF5752 1 ex., Seychelles, tropical mist forest, on a ridge, above La Passe, 540-590 m, 23.08.1984, USSR Zoological Expedition. 


\section{Family Ocnerodrilidae Beddard, 1891}

\section{Maheina braueri (Michaelsen, 1897)}

(Figures 4-6)

Acanthodrilus braueri Michaelsen, 1897a: 22. Maheina braueri: Michaelsen 1899: 237. Notiodrilus braueri: Beddard, 1912: 78.

Material examined. HNHM/AF5710 1 clitellate adult (tail missing) 2 aclitellate adult ex. and one juvenile ex., Seychelles, Mahé, Congo Rouge, moss forest, under fallen log, stones and moss, 19.06.2000, leg. Cs. Csuzdi.

Description. External characters. Length of the aclitellate adult specimens $75-95 \mathrm{~mm}$, diameter 3-3.5 mm, segment No. 215-253-192. Colour alive green, conserved reddish-grey. Prostomium epilobic, dorsal pores lacking. Segments simple, setae eight per segment in widely paired regular rows. Setal formula after clitellum $a a: a b: b c: c d: d d=4.5: 1: 3: 2: 5.5$. Setae of XVII, XIX present, penial setae and genital setae lacking. Spermathecal pores paired, small slits in the intersegmental furrow VII/VIII, VIII/IX in setal line $b$. Clitellum saddle-shaped on XIV-XX. Female pores in XIV, presetal before setae $b$. Two pairs of prostatic pores on two pairs of glandular elevation in XVII, XIX just at the base of setae $b$, joined by curly braces-like seminal grooves, running in setal line $b$. Male pores minute, externally not visible on XVIII, within the seminal grooves. Genital marking are lacking (Fig. 4).

Internal characters. No septa notably thickened. One large oesophageal gizzard in VI. Dorsal vessel single throughout, the last pair of hearts in XI. Excretory system holoic, avesiculate. Two pairs of downward oriented, aubergine-shaped calciferous glands in IX, X (Fig. 5). Intestine begins in XIV, real typhlosole lacking, but a shallow bulging can be seen dorsally from segment XXIV. Metandric. One pair of testis and iridescent male funnel in XI. A single pair of seminal vesicles in XII. One pair of moderatesized ovaries in XIII. Two pairs of small tubular prostates of similar size in XVII and XIX, slightly coiled and confined to their own segment. Penial

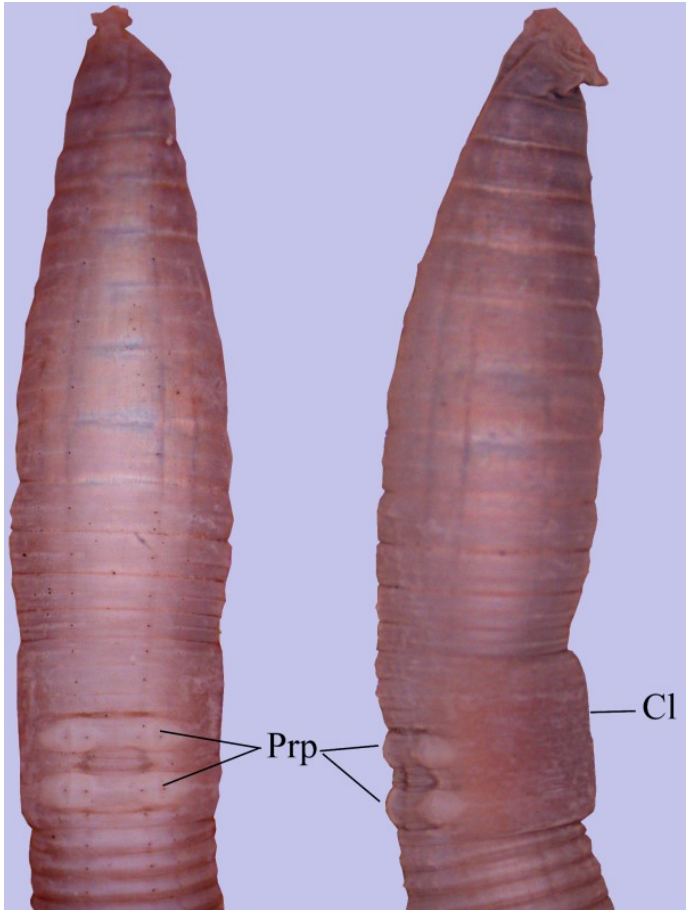

Figure 4. Maheina braueri (Michaelsen, 1897) ventral and ventro-lateral view. $\operatorname{Prp}=$ prostate pores, $\mathrm{Cl}=$ clitellum.

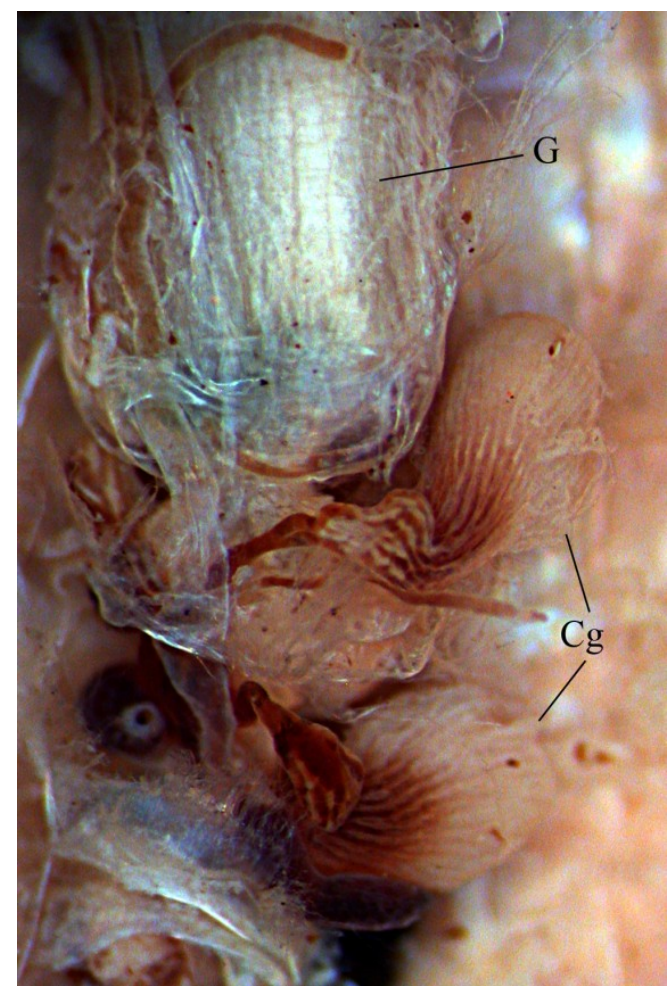

Figure 5. Maheina braueri (Michaelsen, 1897) $G=$ gizzard, $\mathrm{Cg}=$ calciferous glands. 


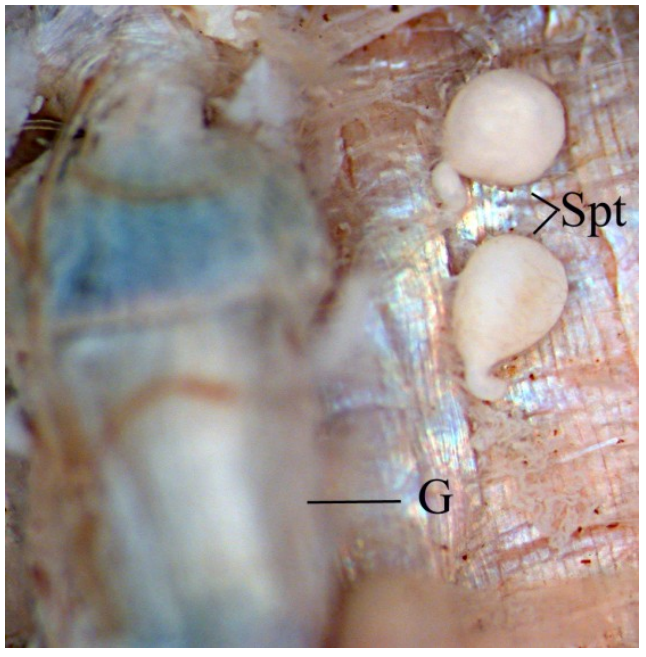

Figure 6. Maheina braueri (Michaelsen, 1897) $G$ = gizzard, Spt $=$ spermathecae

setae lacking. Two pairs of spermathecae in VIII and IX. Ampoule spherical, duct slightly curved, almost as long as the ampoule. Diverticulum lacking. (Fig. 6).

Remarks. This is the first recollection of this interesting species described as Acanthodrilus braueri from Mahé (Seychelles). Later (Michaelsen 1899) relegated it into a new genus Maheina Michaelsen, 1899 of the subfamily Megascolecidae (Acanthodrilinae). After a thorough examination of the paired calciferous glands in X, XI of Maheina Michaelsen (1922) proposed its close relationship to the ocnerodrilid Curgia Michae1sen, 1921 genus (now Curgiona Gates, 1941) possessing unpaired calciferous glands in the very same segments, and transferred Maheina to the subfamily Megascolecidae (Ocnerodrilinae). However, recently, the Drilobase database (http://taxo.drilobase.org) lists it in the family Acanthodrilidae as well as Blakemore (2008b, 2013) and Gerlach (2011). According to the vascular system (last pair hearts in XI) and the paired ocnerodrilid like calciferous glands in IX, X Maheina Michaelsen, 1899 belongs to Ocnerodrilidae and seems to be related to the metandric Southern Indian ocnerodrilid genera Aphanascus Stephenson, 1924 and Curgiona Gates, 1941p.

\section{Family Rhinodrilidae Benham, 1890}

\section{Pontoscolex corethrurus (Müller, 1857)}

Lumbricus corethrurus Müller, 1857: 113.

Pontoscolex corethrurus: Blakemore 2008a: 444. (for complete synonymy)

Material examined. HNHM/AF5161 5 ex., Mayotte, Grande Terre, near the road between Combani and Kahani, under a mango tree, S12 48’43" E4507’35”, 16.10.2005, leg. T. Pavlíček. HNHM/AF5165 5 ex., Mayotte, Grande Terre, Kwalé, S12 ${ }^{\circ} 47^{\prime} 42^{\prime \prime}$ E4509'57”, 330 m, 20.10.2005, leg. T. Pavlíček. HNHM/AF5166 3 ex., Mayotte, Grande Terre, near road CombaniKwalé, S1246'59" E4508'52", 280 m, 20.10. 2005, leg. T. Pavlíček. HNHM/AF5170 7 ex., Mayotte, Grande Terre, along River Bandrani, S12 42’26” E45 05'36”, $160 \mathrm{~m}, 07.10 .2005$, leg. T. Pavlíček. HNHM/AF5175 4 ex., Mayotte, Grande Terre, along River Mro, NE of Dzoumonyé, S12 ${ }^{\circ} 41^{\prime} 58^{\prime \prime} \mathrm{E} 45^{\circ} 05^{\prime} 22^{\prime \prime}, 200 \mathrm{~m}$, natural forest, 08.10.2005, leg. T. Pavlíček. HNHM/ AF5176 2 ex., Mayotte, Grande Terre, lower station of the monte-charge to Mlima Combani, forest reserve, S12 $48^{\prime} 00^{\prime \prime} \mathrm{E} 45^{\circ} 09^{\prime} 14^{\prime \prime}, 440 \mathrm{~m}$, 14.10.2005, leg. T. Pavlíček. HNHM/ AF5187 7 ex., Mayotte, Grande Terre, near Longoni, S12 $43^{\prime} 43^{\prime \prime}$ E45 $07^{\prime} 46^{\prime \prime}, 35 \mathrm{~m}$, around mangrove forest, 04.10.2005, leg. T. Pavlíček. HNHM/ AF5188 1 ex., Mayotte, Grande Terre, along Longoni River, S12 ${ }^{\circ} 44^{\prime} \mathrm{E} 45^{\circ} 10^{\prime}, 40 \mathrm{~m}, 05.10$. 2005, leg. T. Pavlíček. HNHM/AF5190 5 ex., Mayotte, Grande Terre, along river above the Gîtes de Kwalé, S12 $48^{\circ} 30^{\prime \prime}$ E4509'40”, 185 m, 06.10.2005, leg. T. Pavlíček. HNHM/AF5714 7 ex., Mauritius, Montagne Cocotte, moss forest, under moss, $750 \mathrm{~m}, \mathrm{~S} 20^{\circ} 26^{\prime} 5^{\prime \prime}$ E5 5 $7^{\circ} 28^{\prime} 3^{\prime \prime}$, 26.06.2000, leg. Cs. Csuzdi. HNHM/AF5724 4 ex., Mauritius, Petrin, Brise Fer, forest reserve, behind the Gerald Durrell Endemic Wildlife Sanctuary, $625 \mathrm{~m}, \quad \mathrm{~S} 20^{\circ} 22^{\prime} 1^{\prime \prime}$ E5 $7^{\circ} 26^{\prime} 5^{\prime \prime}$, 26.06.2000, leg. Cs. Csuzdi. HNHM/AF5725 2 ex., Seychelles, Mahé, N side of Le Niol, along the road, under leaf litter, 16.06.2000, leg. Cs. Csuzdi. HNHM/AF5726 1 ex., Seychelles, Mahé, cloud forest, $500 \mathrm{~m}$, under Pterocarpus indicus, 
Table 1. Earthworm species found on the different Indian Ocean Islands

\begin{tabular}{|c|c|c|c|c|c|}
\hline & Mayotte & Mauritius & Reunion & Seychelles & Sri Lanka \\
\hline \multicolumn{6}{|l|}{ Acanthodrilidae } \\
\hline Dichogaster (Dt.) annae (Horst, 1893) & + & & & + & \\
\hline \multicolumn{6}{|l|}{ Eudrilidae } \\
\hline Eudrilus eugeniae (Kinberg, 1867) & + & & & & \\
\hline \multicolumn{6}{|l|}{ Lumbricidae } \\
\hline Aporrectodea caliginosa (Savigny, 1826) & & & + & & \\
\hline Bimastos rubidus (Savigny, 1826) & & & + & & \\
\hline \multicolumn{6}{|l|}{\begin{tabular}{|l|} 
Megascolecidae \\
\end{tabular}} \\
\hline Amynthas corticis (Kinberg, 1867) & & & + & & \\
\hline Amynthas gracilis (Kinberg, 1867) & & + & & & \\
\hline Amynthas minimus (Horst, 1893) & & + & & + & \\
\hline Amynthas rodericensis (Grube, 1879 ) & + & + & + & & \\
\hline Amynthas robustus (Perrier, 1872) & & + & + & & \\
\hline ?Diporochaeta sp. & + & & & & \\
\hline Lampito mauritii Kinberg, 1867 & & & & & + \\
\hline Megascolex insignis Michaelsen, 1910 & & & & & + \\
\hline Metaphire bahli (Gates, 1945) & & & & & + \\
\hline Metaphire californica (Kinberg, 1867) & & & + & & \\
\hline Nellogaster bahli (Stephenson, 1925) & & & & & + \\
\hline Pithemera bicincta (Perrier, 1875) & + & & + & & \\
\hline Polypheretima elongata (Perrier, 1872) & + & + & & & \\
\hline Polypheretima taprobanae (Beddard, 1892) & & & & + & + \\
\hline \multicolumn{6}{|l|}{ Ocnerodrilidae } \\
\hline Maheina braueri (Michaelsen, 1897) & & & & + & \\
\hline \multicolumn{6}{|l|}{ Rhinodrilidae } \\
\hline Pontoscolex corethrurus (Müller, 1857) & + & + & + & + & + \\
\hline
\end{tabular}

16.06.2000, leg. Cs. Csuzdi. HNHM/af5729 1 ex., Mauritius, Black River Peak, 600-700 m, 27.06. 2000, leg. Cs. Csuzdi. HNHM/5730 1 ex., Seychelles, Mahé, N side of Le Niol, along a small stream, $350 \mathrm{~m}, 16.06 .2000$, leg. Cs. Csuzdi. HNHM/AF5731 1 ex., Réunion, lowland rain forest, 24.06.2000, leg. Cs. Csuzdi. HNHM/ AF5736 9 ex., Sri Lanka, Kalutara district, Matugama, stream bank near the city, 12.03.2000, S. Mahunka, L. Mahunka-Papp. HNHM/5742 6 ex., Sri Lanka, Kalutara district, Wadduwa, moist meadow near the city, 11.03.2000, leg. S. Mahunka, L. Mahunka-Papp. HNHM/AF5744 2 ex., Sri Lanka, Kalutara district, Moratuwa, near the shore of Bolgoda Lake, 10.03.2000, leg. S. Mahunka, L. Mahunka-Papp. HNHM/AF5747 3 ex., Sri Lanka, Colombo district, Dehiwala-Mount Lavinia, moist area, 09.03.2000, leg. S. Mahunka, L. Mahunka-Papp. HNHM/AF5750 1 ex., Seychelles, Mahé, Morne Blanc, $350 \mathrm{~m}$, secondary tropical rain forest, 01.08.1984, USSR Zoological Expedition. HNHM/AF5753 1 ex., Seychelles,
Silhouette, near La Passe, 22-25.08.1984, USSR Zoological Expedition.

\section{DISCUSSION}

This small scale survey resulted in recording 20 earthworm species on the investigated five islands (Table 1). According to our expectation, the peregrine earthworms dominated on both oceanic and continental islands. The three endemic species found were present only in the continental islands (Maheina braueri in Seychelles and Megascolex insignis, Nellogaster bahli in Sri Lanka) in a contrast to the oceanic ones. Among the peregrine species the wellknown pantropical pheretimoids were the most frequent (10 spp.). To our surprise, the only species occurring in all the investigated islands was the rhinodrilid Pontoscolex corethrurus. Amazingly, at higher elevations in Réunion two peregrine lumbricid species were also collected (Aporrectodea caliginosa and Bimastos rubidus). 
The present survey resulted in recording the type species of the monotypic genera Maheina (M. braueri) and Nellogaster ( N. bahli) for the first time since their original description and also an enigmatic ?Diporochaeta species. The genus Diporochaeta is mainly distributed in Australia and New Zealand (Jamieson 2000) with two doubted records in Southern India (Blakemore 2007). However, these two Diporochaeta species (D. montanus (Gates, 1940) and D. pellucida (Bourne, 1894)) differs markedly from our specimens having strong gizzard in segment $\mathrm{V}$ and last pair of hearts in XII (in our specimens there is no gizzard and the last pair of hearts are in XIII).

Acknowledgements - Our thanks are due to Prof. Barrie Jamieson for his comments on the possible Diporochaeta specimens. This research was supported by the grant EFOP3.6.1-16-2016-00001 ("Complex improvement ofresearch capacities and services at Eszterházy Károly University”)

\section{REFERENCES}

BEDDARD, F.E. (1892): On some species of the genus Perichaeta (sensu stricto). Proceedings of the Zoological Society of London, 1892: 153-172.

BLAKEMORE, R.J. (2007) Checklist of 505 earthworms species from India, Sri Lanka and the adjacent regions (excluding Myanmar) compiled from various sources [e.g. Stephenson (1923), Gates (1972), Julka (1988) etc.]. In: BLAKEMORE, R.J. (Ed.) A series of searchable texts on earthworm biodiversity, ecology and systematic from various regions of the world $-2008,3^{\text {rd }}$ Ed. Available from: http//www.annelida.net/earthworm (accessed 11 September 2019)

BlAKEMORE, R.J. (2008a): Cosmopolitan Earthworm. ( $3^{\text {rd }}$ Edition). VermEcology, Yokohama, Japan. 757 pp.

BLAKEMORE, R.J. (2008b): Review of Southern Ocean, South Atlantic and Subantarctic species after Lee (1994). In. BlaKemORE, R.J. (Ed.) A Series of Searchable Texts on Earthworm Biodiversity, Ecology and Systematics from Various Regions of the World $-3^{\text {nd }}$ Edition. available at http://www.annelida.net/earthworm [accessed 10. September, 2019]

BlAKEMORE, R.J. (2013): The major megadrile families of the World reviewed again on their taxonomic types (Annelida: Oligochaeta: Megadrilacea). Opuscula Zoologica, Budapest, 44(2): 107-127.

CsuZDI, Cs. \& ZICSI, A. (2003): Earthworms of Hungary (Annelida: Oligochaeta; Lumbricidae). In. Csuzdi, Cs. \& MAHunKA, S. (Eds.) Pedozoologica Hungarica 1. Hungarian Natural History Museum, Budapest, $271 \mathrm{pp}$.

Csuzdi Cs., Razafindrakoto, M. \& Blanchart, E. (2012): New and little known earthworm species from Central Madagascar (Oligochaeta: Kynotidae). Zootaxa, 3578: 36-42. doi: $10.11646 /$ zootaxa.3578.1.2

Csuzdi, Cs., Razafindrakoto, M. \& Hong, Y. (2016): The second species of the endemic Malagasy earthworm genus Howascolex Michaelsen, 1901; Howascolex farafangana sp. n. (Clitellata, Megadrili). African Invertebrates, 57(2): 83-91. doi: 10.3897/AfrInvertebr.57.10048

Csuzdi, Cs., Razafindrakoto, M. \& Hong, Y. (2017a): Three new species of Kynotus from the Central Highlands of Madagascar (Clitellata, Megadrili). European Journal of Taxonomy, 336: 1-14. doi: $\underline{10.5852 / \text { ejt.2017.336 }}$

Csuzdi, Cs., Chang, C.-H., PavlíceK, T., SzederJESI, T., EsOPI, D., \& SZlÁVECZ, K. (2017b). Molecular phylogeny and systematics of native North American lumbricid earthworms (Clitellata: Megadrili). PLoS One, 12(8), e0181504. doi:10.1371/journal.pone.0181504

FAtima, Q. \& JAMShed, A. (2015): The Political and Economic Significance of Indian Ocean: An Analysis. South Asian Studies, 30(2): 73-89.

GATES, G.E. (1938): Nellogaster gen. nov. with a note on Indian species of Woodwardiella. Records of the Indian Museum, 40: 426-429.

GATES, G.E. (1945): On some Earthworms from Ceylon II. Spolia Zaylanica, 24: 69-90.

GERLACH, J. (2011): Oligochaeta. In. Gerlach, J. (Ed.) Crustacea, Platyhelminthes, Nematoda, Nemertea, Annelida, Rotifera and Tardigrada of the Seychelles Islands. Siri Scientific Press, Manchester, p. 61-64.

GRUBE, E. (1879): Annelida. In. An account of the petrological, botanical and zoological collections made in Kerguelen's Land and Rodriguez during Transit of Venus Expeditions carried out by order of Her Majesty's Government in the years 1874 
75. Philosophical Transactions of the Royal Society, 168: 554-556. doi: 10.1098/rstl.1879.0057

HoRst, R. (1893): earthworms of the Malay Archipelago. Zoologische Ergebnisse einer reise in Niederländisch Ost-Indien, 3: 28-77.

JAMIESON, B.G.M. (2000): Native earthworms of Australia (Megascolecidae, Megascolecinae). Science Publishers, Inc. Enfield, New Hamphsire, U.S.A., CD Edition, 1518 pp.

KATZ, M.B. (2000): Sri Lanka - India Intraplate Tectonics - Precambrian to Present. Gondwana Research, 3(1): 3-5. doi: 10.1016/S1342-937X(05)70052-6

KINBERG, J.G.H. (1867): Annulata nova. Öfversigt af Königlich Vetenskapsakademiens förhandlingar, Stockholm, 23: 97-103, 356-357.

LJUNGSTRÖM, P.-O. (1971): Earthworms of Mauritius. The Mauritius Institute Bulletin, 7(1): 17-38.

MiCHAELSEN, W. (1897a): Die Terricolen des Madagassischen Inselgebiets. Abhandlungen von der Senckenbergischen Naturforschenden Gesellschaft, Frankfurt am Main, 21: 217-252.

MichaElsEN, W. (1897b): Die Terricolenfauna Ceylons. Jahrbuch der hamburgischen wissenschaftlichen Anstalten 14(2): 157-250.

MiCHAELSEN, W. (1899): Oligochäten von den Inseln des Pacific, nebst Erorterungen zur Systematik der Megascoleciden. Zoologische Jahrbücher, Abteilung für Systematik Ökologie und Geographie der Tiere, 12: 211-246.

Michaelsen, W. (1903): Oligochaeten von Peradeniya auf Ceylon, ein beitrag sur kenntnis des einflusses botanischer garten auf die einschleppung peregriner thiere. Sitzungsberichte der Königlichen Böhmischen Gesellschaft der Wissenschaften, Mathematisch-Naturwissenschaftliche Classe, 55: 1-16.

MichaELSEN, W. (1908): The Oligochaeta of India, Nepal, Ceylon, Burma and the Andaman Islands. Memoirs of the Indian Museum, Calcutta, 1(3): 103-253.

MichAELSEN, W. (1910): Die Oligochäten fauna der vorderindisch-ceylonischen region. Abhandlungen des Naturwissenschaftlichen Vereins in Hamburg, 19(5): 1-108.

MiCHAELSEN, W. (1907a): Oligochaeten von Madagaskar, den Comdren und anderen Inseln des westlichen Indischen Ozeans. Reise in Ostafrika von A. Voeltzkow in den Jahren 1903-05, Wissenschaftliche Ergebnisse 2: 41-50.

MiCHAELSEN, W. (1907b): Neue Oligochaeten von Vorder-Indien, Ceylon, Birma und den AndamanInseln. Jahrbuch der hamburgischen wissenschaftlichen Anstalten, Hamburg, 24: 143-188.

MiCHAELSEN, W. (1922): Oligochäten vom westlichen Vorderindien und ihre Beziehungen zur Oligochätenfauna von Madagaskar und den Seychellen. Mitteilungen aus dem Naturhistorischen Museum in Hamburg, 38: 27-68.

MitTermeier, R.A., TURner, W.R., LARSEN, F.W., BROOKS, T.M. \& GASCON, C. (2011): Global biodiversity conservation: the critical role of hotspots. In: Zachos, F.E., HABEL, J.C. (Eds.) Biodiversity Hotspots. Springer Publishers, London, p. $3-22$.

PERRIER, E. (1872): Recherches pour servir à l'histoire des lombriciens terrestres. Nouvelles Archives du Muséum d'Histoire Naturelle de Paris, 8: 5-198. doi: 10.5962/bhl.title.12201

PERrIER, E. (1875): Sur les vers de terre des îles de Philippines et de la Cochinchine. Les Comptes Rendus de l'Académie des sciences, Paris, 81: 10431046.

RAZAFINDRAKOTO, M., CSUZDI, Cs., RAKOTOFIRINGA, S. \& BLANCHART, E. (2010): New records of earthworms (Oligochaeta) from Madagascar. Opuscula Zoologica (Budapest) 41: 231-236.

RAZAFIndraKoto, M., Csuzdi, Cs. \& Blanchart, E. (2011): New and little known giant earthworms from Madagascar (Oligochaeta: Kynotidae). African Invertebrate,s 52: 285-294. doi: 10.5733 /afin.052.0205

RaZAFIndRaKoto, M., Csuzdi Cs., James, S.W. \& BLANCHART, E. (2017): New earthworms from Madagascar with key to the Kynotus species (Oligochaeta: Kynotidae). Zoologischer Anzeiger 268: 126-135. doi: 10.1016/j.jcz.2016.08.001

SAVIGNY, J.C. (1826). Analyses des travaux de l'Academie Royale des Sciences pendant l'annee 1821, partie physique. In. CUVIER, G. (Ed.) Mémoirs d'Académie Royale des Sciences Institute de France, 5: $176-184$

STEPHENSON, J., (1913): On a collection of Oligochaeta, mainly from Ceylon. Spolia zeylandica, 8: 251-276. 
StePHENSON, J. (1915): On some Indian Oligochaeta mainly from southern India and Ceylon. Memoirs of the Indian Museum, 6: 35-108.

STEPHENSON, J. (1923): Oligochaeta. In. SHIPLEY, A.E. \& ScOTT, H. (Eds.) The fauna of British India including Ceylon and Burma. Taylor and Francis Inc., London, 518 pp.
WALKER, H.J., INGOLE, B., NAYAK, G.N., WAFAR, M., WAFAR, S., YENNAVAR, P. \& LAMBECK, K. (2005). Indian Ocean Islands, Coastal Ecology and Geomorphology. In. FINKL, C.W. \& MARKOWSKI, C. (Eds.) Encyclopedia of Coastal Science, Springer Nature, p. 557-564. doi: $10.1007 / 1-4020-3880-1 \quad 180$ 